\title{
CRACK: THE BROKEN PROMISE
}




\section{Crack: \\ The Broken Promise}

DAVID F. ALLEN, M.D., M.P.H.

Lecturer in Public Health

Yale University School of Medicine

and

JAMES F. JEKEL, M.D., M.P.H.

Professor of Epidemiology and Public Health

Yale University School of Medicine

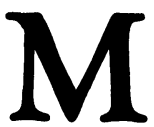

MACMILLAN

PRESS

Scientific \& Medical 
All rights reserved. No reproduction, copy or transmission of this publication may be made without written permission.

No paragraph of this publication may be reproduced, copied or transmitted save with written permission or in accordance with the provisions of the Copyright, Designs and Patents Act 1988 or under the terms of any licence permitting limited copying issued by the Copyright Licensing Agency, 33-4 Alfred Place, London WC1E 7DP.

Any person who does any unauthorised act in relation to this publication may be liable to criminal prosecution and civil claims for damages.

First published 1991

Published by

MACMILLAN ACADEMIC AND PROFESSIONAL LTD

Houndmills, Basingstoke, Hampshire RG21 2XS

and London

Companies and representatives

throughout the world

British Library Cataloguing in Publication Data

Allen, David F. \& Jekel, James F.

Crack, The Broken Promise

- (Pharmaceutical series)

I. Title

ISBN 978-0-333-49972-6

ISBN 978-1-349-21433-4 (eBook)

DOI 10.1007/978-1-349-21433-4

NOTE: The opinions expressed in this book are not necessarily those of the institutions and programs with which the authors are affiliated. 
To our parents, who taught us to love what is good, and to our wives, who have surrounded us with love and goodness.

DFA \& JFJ 


\section{Contents}

Foreword, by Frank Gawin $\quad$ ix

Preface $\quad$ xi

$\begin{array}{ll}\text { Introduction } & 1\end{array}$

$\begin{array}{lll}1 & \text { The crack crisis } & 7\end{array}$

Why now?

A brief chronology of the current epidemic $\quad 11$

$\begin{array}{ll}\text { Patterns of spread of drug use } & 17\end{array}$

2 Crack addiction: a clinical perspective 21

Modes of action of crack $\quad 21$

Dynamics of crack abuse $\quad 22$

Physical symptoms $\quad 24$

Psychological effects $\quad 26$

Social effects $\quad 29$

3 Crack addiction in the home, school, and workplace 33

Signs of crack abuse $\quad 33$

The family and drugs $\quad 37$

Crack addiction and the school $\quad 42$

Crack and the workplace $\quad 46$

4 The treatment of crack addiction 52

Who comes for treatment $\quad 52$

The goal of treatment $\quad 52$

The principles of treating crack addicts 53

Inpatient or outpatient treatment? 54

Treatment program components $\quad 56$

Other types of drug program 63

Illustrative cases of treatment $\quad 64$ 
5 Prevention of crack abuse $\quad 70$

$\begin{array}{ll}\text { Possible causes of the crack epidemic } & 70\end{array}$

Public health models of prevention $\quad 72$

Levels of prevention $\quad 77$

What can be done? $\quad 80$

6 The societal challenge of crack addiction 84

Individuals and families $\quad 84$

Poor neighborhoods $\quad 84$

Social order and legal authority $\quad 85$

Should crack sale and use be legalized? $\quad 87$

A national response $\quad 90$

International efforts $\quad 94$

Future drug problems: Ice $\quad 95$

$\begin{array}{lr}\text { Postscript } & 99\end{array}$

Appendix A

A glossary of street drugs and drug terms 103

Appendix B

Rules for drug dependence $\quad 105$

Appendix C

Fourteen basic steps to recovery

106

Appendix D

Some inexpensive reference sources

112

Index

114 


\section{Foreword}

Cocaine is a chemical: a crystalline, odorless, colorless alkaloid, solid at room temperature. It is not a scourge or a demonic entity. Nor is it, itself, villainous, insidious, seductive or marvellous. It is not a salvation or a panacea. Of course, there are many claims that it is each of these. Cocaine easily passes from the blood into the brain. There it fits onto a specific few nerve cells in the brain in a way that amplifies the signals they transmit. Very unfortunately, those nerve cells regulate experiences of joy and pleasure, and the action of these cells, when first exposed to cocaine, is to produce intense feelings of well-being. We humans then assume a promise: that, when used again, and again, the cocaine crystals will have the same effect, and that if we use even more, the only result will be more pleasure. We thus extract a promise from cocaine, demanding that it continue to provide great joys, attained, in comparison to the normal pleasures in life, with astonishing ease. While the promise is alive, we call cocaine a euphoriant, an antidepressant, a therapeusis, and sometimes a salvation or a panacea. Because the brain adapts to external perturbations, including the presence of the cocaine crystals, the promise dies an inevitable death. Attempts to resurrect the promise destroys will and lives. We tend to blame the substance and neither the brain or ourselves, the extractors of the promise, and then label cocaine as villainous or seductive, as a demonic substance and scourge.

In Crack: The Broken Promise Allen and Jekel superbly explain the incomprehensible. How is it that crack cocaine can destroy judgement, will, and lives? And how is it that, sometimes, one can recover from this broken promise? It is difficult to find reasoned assessments of crack and even more rare to find clear descriptions of its effects - descriptions that neither distort, sensationalize, or misplace the key factors in cocaine addiction. The authors of Crack: The Broken Promise have been forced into reasoned assessments, and they ably share those assessments with us.

Dr Allen was the first to be faced with the spectre of 'crack' cocaine, which appeared first in the Bahamas almost a decade ago, and thus also the first treater faced with the need to respond 
to cries for help with crack addiction. His experience of almost a decade as the treatment leader in his nation's battle against 'crack' is unequalled. He has seen and treated all of the extremes of crack addiction. Dr Jekel has long experience in public health and its interactions with human behavior, and has been especially concerned with the human face of epidemics. He has catalogued the 'crack' epidemic from its origins in the Bahamas to its spread to the United States. Together, with the wisdom born of experience, they provide a complete view of crack, from the micromoment of a transient paranoid thought in a user to the behavior of nations over decades. Avoiding both oversimplification and unnecessary complication, they provide both the foundation and the details necessary for the concerned layman to understand and generate an informed response to 'crack' cocaine addiction.

Important questions face us about crack addiction. Will crack addiction spread? Where? How rapidly? In what communities? Will it pave the way for other drugs? Could other drugs be more powerful or more addictive? How did prior cocaine epidemics end? Will this one? How is this epidemic different? How does one act responsibly as a parent in an age of 'crack'? How does one identify early crack use? How does one intervene? How does crack work? How is crack different from other drugs? How and in what way does it change the addict? Does it change the brain or is it only a 'psychological' addiction? How often does recovery occur? In whom? What measures best help crack addicts? Which measures for which addicts? How long does it take recovery to occur? How potentially effective, or important, is prevention? What do the clinical effects of crack indicate for public policy decisions? What would be the consequences of legalization? How can we help and protect ourselves, our children, our friends, our communities, our countries? With clarity and essential brevity, Allen and Jekel provide the reader with the background to understand the complexities of these questions, to understand the answers that we have, and to understand the answers that we yet need.

FRANK GAWIN, MD Director of Stimulant Abuse Treatment and Research Yale University School of Medicine April 1990 


\section{Preface}

Our goal in this book is to provide health professionals and informed citizens throughout the world with a basic understanding of the worldwide epidemic of 'crack' cocaine abuse and an early warning of the kind of problem countries will probably face if they do not treat crack cocaine as the grave danger it is, and act accordingly. We discuss the disease, its history, treatment, and prevention, and some alternative strategies for control. We desire that other countries will take appropriate warning from what the Americas have suffered, in order to prevent a similar agony for themselves.

Many readers may suspect we exaggerate the dangers of freebase 'crack' cocaine. The Americas, however, ignored the warnings of many people (including ourselves) about the growing danger of crack cocaine until the crisis was upon them. The new dimensions of cocaine make it even more serious than during the first decade of this century, and many times as serious as cocaine seemed to be during the mid-1970s. If this book results in even a small increase in awareness and preparedness of individuals and nations for their struggle against crack cocaine, our efforts will have been well rewarded.

Ultimately the most important resource for resisting a widespread problem is the will and determination of the people, which requires that they understand the enemy, including how it threatens their most precious values and traditions. We hope this book will provide for its readers the basic information they need to understand and resist crack cocaine.

The discussion of the clinical aspects and treatment of crack abuse is intended to give readers enough information about signs and symptoms to detect crack abuse early in others and to assist effectively in the treatment of others, should that ever become necessary. Understanding the complexity of treatment also helps to clarify the true nature of cocaine abuse.

We also want this volume to provide basic information for policy makers unfamiliar with crack. We make no claim that this book is a complete information source for any group, but those who want more information can consult the various sources quoted here.

We are most grateful to our colleague, Frank Gawin, M.D., for his willingness to review the manuscript, make suggestions for 
improvement, and write the Foreword. His extensive knowledge and experience, and his special insight into the crack problem, improved the manuscript considerably. The responsibility for any errors and shortcomings, however, is ours alone.

With deepest gratitude we thank our wives, Vicki and Jan, for their unflagging support of this effort, despite the fact that for months it took much of the limited time we had 'just for them'. Beyond that, they were our editors, never failing to encourage us and yet never hesitating to tell us when a section needed rewriting. If this book is clear and informative to others, much of the credit belongs to them.

DAVID F. ALLEN

Nassau, Bahamas

JAMES F. JEKEL

New Haven, CT

May 1990 